\title{
Identification of cellular enhancing and restricting factors of dengue virus egress
}

\author{
Pei Gang Wang ${ }^{*}$, Mateusz Kudelko, Kevin Kwok, Roberto Bruzzone, Beatrice Nal \\ From Institut Pasteur International Network Annual Scientific Meeting \\ Hong Kong. 22-23 November 2010
}

Dengue has emerged as the most important life-threatening illness in the world, especially in Asian countries around Hong Kong, where the incidence of dengue hemorrhagic fever (DHF) is much greater than other continents. However, little is known about molecular and cellular processes sustaining egress of dengue virus in the host cell.

To better understand the viral and cellular determinants of dengue virus egress, we have established a dengue VLP producing stable cell line (HeLa-prME) and demonstrated that dengue VLP was able to mimic the budding and egress process of dengue viruses so that it constitutes a safe and convenient tool for the study of egress of dengue virus. Under the support of RFCID grant, HeLa-prME cells were used to screen a siRNA library that included 122 cellular membrane trafficking genes.

Our screen results revealed that knockdown of ADPribosylation factor (ARF) 1 and ARF6 had significant effects on VLP production by HeLa-prME cell. Experiments with other ARF proteins, which were not included in the siRNA library, showed that the ARF4/ ARF5 double knockdown could inhibit VLP production but had no effect on secretion of other proteins such as soluble dengue E protein, suggesting the specificity of their involvement in VLP production. Further experiments using real virus showed that the depletion of ARF4/5 by siRNA could significantly reduced the replication of dengue 1 virus, dengue 4 virus and yellow fever virus, confirming the important role of ARF4 and ARF5 for not only dengue viruses but also other flaviviruses.

Our study uncovered the importance of class II ARFs in the egress of dengue virus. Results from this project

HKU-Pasteur Research Centre, Hong Kong, Hong Kong SAR provided information on mechanism of dengue virus assembly and its dependence on cellular machineries.

Published: 10 January 2011

doi:10.1186/1753-6561-5-S1-P51

Cite this article as: Wang et al:: Identification of cellular enhancing and restricting factors of dengue virus egress. BMC Proceedings 2011 5(Suppl 1): P51.
Submit your next manuscript to BioMed Central and take full advantage of:

- Convenient online submission

- Thorough peer review

- No space constraints or color figure charges

- Immediate publication on acceptance

- Inclusion in PubMed, CAS, Scopus and Google Scholar

- Research which is freely available for redistribution
() Biomed Central

\section{Biomed Central}

(c) 2011 Wang et al; licensee BioMed Central Ltd. This is an open access article distributed under the terms of the Creative Commons Attribution License (http://creativecommons.org/licenses/by/2.0), which permits unrestricted use, distribution, and reproduction in any medium, provided the original work is properly cited. 